\title{
Tendências criminais e punitivas na província de São Paulo na segunda metade do século XIX
}

\author{
Criminal and punitive trends in the province of São Paulo in the second half of the I9th \\ century
}

\section{Adalmir Leonidio*}

Resumo: Este artigo busca mostrar que nas condições atrasadas do capitalismo brasileiro da segunda metade do século XIX, o sistema penal cumpria um duplo propósito: disciplinar o trabalho e reduzir os desvios. Assim também em relação aos métodos punitivos: suplício para uns, isolamento ou trabalho forçado para outros. Estas indefinições jurídicas tinham a ver com as diferenças hierárquicas estabelecidas dentro da própria sociedade brasileira desde o período colonial.

Palavras-chave: Crime, Punição, São Paulo, Século XIX

Abstract: This paper aims to show that in the late Brazilian capitalism conditions of the second half of the nineteenth century, the penal system fulfilling a dual purpose: disciplinary work and reduce errors. So also with regard to punitive methods: torture for some, isolation or forced labor for others. These legal uncertainties had to do with the hierarchical differences established within the Brazilian society since the colonial period

Keywords: Crime, Punishment, São Paulo, XIX Century

* Livre Docente pela Universidade de São Paulo. Pesquisa financiada pela FAPESP. 


\section{Introdução}

Estudar as tendências criminais e punitivas de uma época é entender o que esta época considera ou não como crime. Porque as relações entre crime e castigo não são uma relação linear, como faz supor o senso comum criminológico, como se a cada crime correspondesse uma pena e a cada pena um crime. Há ações que são claramente definidas pela lei como crime, mas que não são alvo de repressão pelo sistema punitivo. Este é o caso, por exemplo, dos crimes sexuais no Brasil na segunda metade do século XIX. Raríssimos eram os casos de crimes desta natureza punidos neste período. Do mesmo modo, há ações que não são claramente definidas pela lei como crime, mas que são no entanto alvo de severa repressão. Este é o caso das rebeliões de escravos (ou até mesmo de qualquer outro crime praticado por escravo, que encontrava na lei muitas brechas penais). Há ainda ações que não eram consideradas crime e que repentinamente passaram a sê-lo. Este é o caso, por exemplo, da vadiagem, em fins do século XIX.

Mas é entender também a que classes sociais referem-se os crimes passíveis de punição. Estas classificações, que têm a ver com o desejo de ordem, são sempre históricas. Neste artigo estaremos centrados na segunda metade do século XIX, por ser este um período que indica claramente uma tendência, o predomínio dos crimes contra a pessoa, embora haja em seu interior diferentes classificações, no que se refere às tendências punitivas. Os crimes cometidos por escravos eram claramente punidos de forma distinta dos crimes cometidos por livres, embora não houvesse uma legislação específica para um caso e outro. Aliás, esta ausência de uma situação jurídica definida dos escravos acabava por reforçar estas diferenças punitivas, uma vez que tendiam para punições extrajudiciais. Assim também se dava com os crimes de honra, que tendiam para a impunidade, mormente aqueles praticados entre vizinhos e amigos.

Em suma, o problema das classificações nos obriga a pensar o problema das estatísticas do período, uma vez que trabalhamos aqui alguns dados desta natureza. Podese dizer que até I884 não existe um serviço de estatística criminal regular. Em sendo assim, a maior parte dos dados deste tipo são extraídos dos relatórios dos chefes de polícia provinciais, a maior parte deles cheios de vieses. Tais dados apresentam, em geral, muito pouco rigor em relação à realidade dos crimes praticados. Mas eles indicam com certa clareza o que era e o que não era tolerado pela sociedade brasileira da segunda metade do século XIX. Eis aí o que entendemos por "tendências criminais e punitivas" neste contexto. Eis aí o objeto deste artigo. 


\section{Tendências criminais e punitivas no mundo moderno}

Como dito, o crime é uma construção social, portanto só se define no âmbito de uma ordem socioeconômica e política determinada (BATISTA, 20I4; HOBSBAWM, 20I5). Como bem mostrou Michel Foucault em seu estudo já clássico, entre fins do século XVIII e início do século XIX, mudam-se os crimes puníveis, bem como o objeto das ações punitivas, apontando para uma clara mudança de tendência. Diminuem os crimes violentos e aumentam os crimes contra a propriedade, bem como substitui-se o suplício pela pena privativa de liberdade (FOUCAULT, 1986). Contudo, o que não fica claro neste autor é se há de fato diminuição dos crimes violentos - crimes de sangue e agressões físicas -, ou se há uma mudança apenas na tendência punitiva. Sabe-se, por exemplo, que em muitas partes da Europa, como a Escócia do século XIX, matar em defesa da honra não era considerado crime, sendo que os réus submetidos a julgamento, via de regra, eram absolvidos pelo júri (HOBSBAWM, 2015, p. 22).

Mas pode-se admitir, ao menos hipoteticamente, uma redução dos crimes violentos a partir de fins do século XVIII em certas regiões da Europa Ocidental, se se considerar o avanço daquilo que Norbert Elias chamou de "processo civilizatório", relacionado sobretudo a um maior controle das emoções em uma sociedade crescentemente formalizada em suas relações sociais (ELIAS, 20II). Admitindo-se esta tendência, há que se explicar as razões estruturais mais importantes do crescimento do número de crimes contra a propriedade: multiplicação das riquezas e das propriedades, sem dúvida, mas também da miséria e da exclusão social; aumento da demanda por segurança, também é outro fator de destaque, correlativamente; mas também aumento das intervenções punitivas, uma vez que vários crimes que antes não eram punidos e, portanto, não eram propriamente crimes, agora passam a sê-los: vadiagem, roubo, furto. Neste caso, parece haver uma relação direta, quase linear, entre crime e punição: os crimes contra a propriedade não eram punidos antes do século XVIII porque eram raros, tendência que se inverte a partir daí (FOUCAULT, 1986).

Foucault argumenta que a mudança nos métodos punitivos, do corpo para a alma, do que o indivíduo fez para o que ele é ou representa (sua tendência ou propensão ao crime), parece estreitamente relacionada à mudança nos mecanismos classificatórios dos crimes, na passagem do século XVIII para o XIX. E esta mudança de tendência está relacionada a uma outra tendência: o crescimento do sistema industrial. Isto não apenas em relação ao crescimento da riqueza e da pobreza, simultaneamente, como partes estruturais do mesmo processo, mas também em relação à constituição de um sistema de 
sujeição do corpo, de modo a torna-lo apto à força de trabalho na indústria (FOUCAULT, I986).

Mas na passagem de um método punitivo a outro, do suplício ao cárcere, há toda uma mudança de tendência que é preciso apontar. E foram Melossi e Pavarini quem melhor mostraram uma tal mudança de tendência nos métodos punitivos, entre os séculos XVI e XVIII. Segundo eles, cada sistema de produção descobre o sistema de punição que corresponde às suas relações produtivas. Num sistema de produção pré-capitalista, o cárcere como pena não existe. Ainda que o cárcere exista nestas sociedades, ele não cumpre a função punitiva (internamento como privação da liberdade por um tempo determinado, um quantum de liberdade abstratamente determinado). As penas eram de outro tipo. O equivalente do dano produzido pelo delito se realizava na privação daqueles bens socialmente considerados como valores: a vida, a integridade física, a perda do status (MELOSSI \& PAVARINI, 2006, p. 22).

No início do processo de expropriação, no século XVI, como não havia ainda mão de obra suficiente para formar o exército de reserva, era preciso forçar as pessoas ao trabalho, com leis anti-vadiagem ou com a criação de "casas de trabalho" ("workhouses"). Seu propósito era duplo: disciplinar o trabalho e desencorajar a vadiagem. Tais casas multiplicam-se ao longo dos séculos XVI e XVII na Inglaterra, na França e na Holanda (MALOSSI \& PAVARINI, 2006, p. 33-40). Como mostrou Marx, o aprendizado da disciplina da nova situação -transformação repentina de camponeses em operários de fábrica - é uma das finalidades fundamentais às quais, em sua origem, o capital teve de se propor (MARX, 20I4). Também Weber argumenta que o trabalho, como um fim absoluto em si mesmo, não é um produto da natureza, mas o resultado de um "árduo processo educativo" (WEBER, 2007, p. 57). Neste processo educativo, várias instituições assumirão papel de relevo, ao longo do desenvolvimento do capitalismo industrial: a fábrica, a escola, a religião, etc. $\mathrm{O}$ argumento de Pavarini é que neste limiar do nascimento das fábricas, as casas de correção parecem ter tido um papel vital.

Mas à medida que o capitalismo avança, as casas de correção representam uma concorrência com o trabalho das fábricas, deixando de ser o fator de controle do trabalho para ser um obstáculo. A partir daí, a disciplina do trabalho se dá no processo de produção, bem como no próprio mercado, por meio da criação de uma superpopulação relativa. A força extra-econômica agora é algo excepcional, uma exceção. A questão agora passa a ser o que fazer com aqueles que não encontram ou que têm escassas chances de encontrar um lugar no mercado de trabalho. A antesala do "grande encarceramento" é o "grande medo" que se alastra pela Europa em fins do século XVIII, à medida que se alastram a miséria e o 
crime. É neste preciso momento que tem início a pena privativa de liberdade como forma punitiva privilegiada. O objetivo não é mais disciplinar para o trabalho, mas simplesmente disciplinar, estabelecer um controle social sobre os indesejáveis destroços do exército industrial de reserva (MELOSSI \& PAVARINI, 2006, p. 89-93).

Sem dúvida, estamos a observar uma justiça crescentemente mais vigilante e atenta ao corpo social. Neste sentido, o prejuízo que um crime traz ao corpo social é a desordem que introduz nele. O criminoso é aquele que rompeu o pacto social, é inimigo da sociedade inteira. Desqualificado como cidadão, aparece como celerado, monstro, etc. O castigo disciplinar tem aí a função de reduzir os desvios. Deve, portanto, ser essencialmente corretivo. A arte de punir, no regime do poder disciplinar, não visa nem a expiação, nem mesmo a repressão; visa a normalização (FOUCAULT, 1986, p. I63). Normalização que tem a ver com uma lógica do mercado: estandartização, homogeneização, etc.

Em outras palavras, as prisões não se destinam a suprimir as infrações. É uma "maneira de gerir as ilegalidades, de estabelecer limites de tolerância, de dar terrenos a alguns, de fazer pressão sobre outros, de excluir uma parte, de tornar útil outra, de neutralizar estes, de tirar proveito daqueles" (FOUCAULT, I986, p. 240). Trata-se de um mecanismo de dominação. Neste sentido, pode-se dizer que as penalidades existem para punir certas ilegalidades, aquelas relacionadas às classes mais pobres, mas não outras. Relaciona-se com a posição de poder e as necessidades de ordem de uma determinada classe social (BATISTA, 20I4, p. 23).

Mas quem são essas "classes mais pobres"? Segundo Marx, a acumulação capitalista sempre produz uma população trabalhadora supérflua relativamente, isto é, que ultrapassa as necessidades médias da expansão do capital, tornando-se, desse modo, excedente. Tratase daquilo que o autor chama de "lei do decréscimo progressivo da magnitude relativa do capital variável" (e aumento do capital constante) e seus efeitos sobre a população supérflua. "Mas, se uma população trabalhadora excedente é produto necessário da acumulação ou do desenvolvimento da riqueza no sistema capitalista, ela se torna, por sua vez, a alavanca da acumulação capitalista” (MARX, 20I4, p. 743). Em outras palavras, a produção de uma população excedente em relação às necessidades do capital é condição vital para o desenvolvimento da indústria moderna.

O que se chama aqui de superpopulação relativa são, portanto, todos os trabalhadores desempregados ou parcialmente empregados no setor formal da economia. São três as formas desta superpopulação: a flutuante, composta por trabalhadores ora atraídos, ora repelidos pela indústria; a latente, composta por trabalhadores do campo à espera de uma oportunidade na indústria; e a estagnada, composta por trabalhadores 
irregulares, cuja condição de vida se situa abaixo do nível médio de vida normal da classe trabalhadora (os mais explorados). São continuamente recrutados para suas fileiras os que se tornam supérfluos na grande indústria e na agricultura. A estas três Marx acrescenta uma quarta, aqueles lançados na indigência e no pauperismo, que consiste em três categorias: os aptos para o trabalho; os órfãos e filhos de indigentes; os degradados, desmoralizados, incapazes de trabalhar (velhos, deficientes, doentes, etc.), "asilo dos inválidos", "peso morto do exército industrial de reserva" (MARX, 20I4, p. 752-756).

Marx não inclui na superpopulação relativa o chamado lumpemproletariado ou lumpesinato. Há mesmo em Marx, bem como em boa parte da esquerda desde então, um profundo desprezo pelo lumpem. O termo aparece em Marx pela primeira vez em I845, em A ideologia alemã, como "o mais baixo estrato da sociedade". Em O manifesto comunista (I848), aparece como o "produto passivo da putrefação das camadas mais baixas da velha sociedade"; "suas condições de vida o predispõem mais a vender-se à reação". Em As guerras camponesas na Alemanha (I850), de Engels, aparece como "a massa citadina excluída do direito de cidadania": "desocupados", "vagabundos", "mendigos", “diaristas"; “o lumpemproletariado, a escória dos elementos depravados de todas as classes, com sua base nas cidades, é o pior de todos os possíveis aliados. Essa ralé é absolutamente venal e absolutamente descarada”. (GUIMARÃES, 2008, p. 22-23). Em O I8 Brumário de Luís Bonaparte (I852) ele vai apresentar uma lista elaborada daqueles que compunham esta camada social: "roués decadentes", "arruinados e aventureiros rebentos da bueguesia", "vagabundos", "presidiários libertos", “forçados foragidos das galés", "chantagistas", “saltimbancos", "punguistas", “trapaceiros”, “jogadores”, “donos de bordeis", "literati”, "tocadores de realejo", "trapeiros", “amoladores de facas”, "soldadores”, “mendigos”, "em suma, toda a massa indefinida e desintegrada, que os franceses chamam la bohème"; "escória", "refugo", "rebotalho de todas as classes" (MARX, s.d., p. 243)

Pode-se assim fazer uma aproximação da ideia de lumpem ou declassés com a de "classes perigosas". A expressão designa o conjunto social formado à margem da sociedade civil e surgiu na primeira metade do século XIX, num período em que a superpopulação relativa ou o exército industrial de reserva atingia proporções extremas na Inglaterra. Eram formadas pelas pessoas que houvessem passado pela prisão ou as que, por ela não tendo passado, já vivessem notoriamente da pilhagem e que se tivessem convencido de que poderiam, para o seu sustento e o de sua família, ganhar mais praticando furtos do que trabalhando (GUIMARÃES, 2008, p. 2I). Hobsbawm vai estabelecer a distinção entre os "criminosos comuns" (as classes perigosas) e os "bandidos sociais", considerados pela sociedade como heróis, vingadores ou pessoas que lutam pela justiça (embora o Estado os 
considere criminosos comuns), sem esconder, assim, seu desprezo pelos primeiros (HOBSBAWM, 2015). Na retórica foucaultiana, seriam todos os elementos desviantes da norma desejada, mas que, bem entendido, são parte estruturante dela (FOUCAULT, I986)

Mas é preciso insistir ainda uma última vez no fato de que o Estado, ao criar seus inimigos e apresentar a solução para o problema, ele também se legitima como tal. Daí a necessidade das classificações de que lança mão. Segundo Raúl Zaffaroni, as pessoas puníveis pelo Estado, na verdade constituem-se de não-pessoas, perigosos, inimigos da sociedade. Esta situação, que é própria dos estados absolutos (de exceção), está em contradição com a essência do Estado de Direito (apesar de no direito penal moderno continuar a existir a ideia de inimigo da sociedade). Isto é, mesmo no Estado de direito o poder punitivo continua tratando alguns seres humanos como se não fossem pessoas e a legislação autoriza ele a agir assim (ZAFFARONI, 20I4, p. II)

Segundo a lógica do Direito Penal moderno, existe uma clara diferença entre cidadãos (pessoas) e inimigos (não-pessoas, seres humanos privados de certos direitos individuais), visão esta incompatível a ideia de Estado democrático de direito. O Direito Penal, assim procedendo, coisifica as pessoas. Esta coisificação, apesar de ser uma aberração na ordem democrática, é compatível com o processo do capitalismo (LUKÁCS, 1989). Assim, as medidas de segurança daí derivadas configuram-se como mera contenção, impedimento físico de um ente perigoso, contrariando a Declaração dos Direitos do Homem e do Cidadão. Trata-se de um modelo inquisitorial, característico de estados de exceção, que tem na perseguição impetrada a perseguição a inimigos e opositores do regime um fato político primordial. Isto é, o Direito Penal, o cárcere, existe para os inimigos, mas não para as classes dominantes e seus protegidos.

\section{Prelúdio de uma história}

Como mostrou Caio Prado Jr., a escravidão exerceu ampla influência na organização da vida social brasileira. Antes e acima de tudo, o escravo foi o fator principal do trabalho, no campo ou na cidade, nas atividades produtivas ou no interior dos lares (PRADO Jr., 1995). Desta onipresença da escravidão, resultarão várias coisas. Primeiramente, a imagem construída em torno do trabalho, atividade própria de escravos e não de homens livres. Depois, as imensas dificuldades que os próprios senhores terão de lidar com o trabalhador livre, nas poucas situações em que este se relaciona com o processo produtivo na colônia. Em outras palavras, a escravidão não educa a sociedade para o trabalho, antes deplora o próprio trabalho. Há também que se mencionar o profundo 
estigma social lançado sobre os escravos, estigma que nasce de sua condição social, mais que de sua cor, que apenas vem agravar a diferença social profunda que havia entre negros e brancos colonizadores. É neste preciso sentido que o negro - mas também os pardos constituirá sempre um corpo estranho e incômodo da sociedade brasileira (PRADO Jr., 1995, pp. 269-275).

Mas desta onipresença da escravidão, resultará ainda uma forma peculiar de estruturação das classes no Brasil colonial, cujos efeitos serão de longa duração. Àqueles que não são senhores, nem escravos, nem capital, nem trabalho, os homens pobres e livres, restarão poucas opções na ordem produtiva: feitor, mestres de engenho, funções públicas, armas, comércio (privilégio dos reinóis), profissões liberais (acesso restrito), etcetera (PRADO Jr., 1995, pp. 279-280). Nos centros urbanos, sobretudo depois do Independência, o trabalho se complexifica consideravelmente. Ao lado do comércio, avolumam-se as atividades ligadas ao artesanato e à política (COSTA, 1994). Contudo, as condições que inibiram o desenvolvimento urbano durante o período colonial continuaram a atuar durante a primeira metade do século XIX, isto é, a continuidade da escravidão e da economia agroexportadora. Apesar do aumento populacional das cidades, a maior parte da população continuará a residir e trabalhar no campo. Em assim sendo, as atividades mercantis e fabris continuarão inexpressivas no movimento global da economia.

Constitui-se, assim, uma ordem que é feita para excluir. Se por um lado, senhores e escravos constituem os bem classificados da ordem social (fator capital e fator trabalho), entre uns e outros, comprime-se uma imensa massa de pessoas, os homens pobres e livres, os desclassificados, com ocupações incertas e aleatórias, não apenas durante o período colonial, como também ao longo de todo século XIX. Compõe-se sobretudo de pretos e mulatos forros e fugidos da escravidão; índios desligados de sua vida original; mestiços de todos os tipos; até brancos. Uma parte destes desclassificados é composta por aqueles que vegetam pelo interior do Brasil: tapuias ${ }^{\mathrm{I}}$, caboclos, quilombolas; outra parte são os agregados ou moradores de favor dos engenhos. São o refugo da ordem do trabalho, aquilo que nas condições atuais do capitalismo é chamado de precariado (BRAGA, 20I5). Mas há ainda uma terceira categoria de desclassificados, a parte "mais degradada, incômoda e nociva", "a dos desocupados permanentes, vagando de léu em léu à cata do que se manter e que, apresentando-se a ocasião, enveredam francamente pelo crime. É a casta numerosa dos vadios" (PRADO Jr., I995, p. 283).

\footnotetext{
${ }^{\mathrm{I}}$ Vejam que tapuias, que quer dizer inimigos, é a forma como os portugueses referiam-se aos índios no início do processo de colonização (RIBEIRO, 2006).
} 
Vadio aqui não é sinônimo de desclassificado, homem pobre e expropriado, como supôs Laura de Mello e Souza (1986). Trata-se, na verdade, de uma categoria de desclassificados, a "mais degradada, incômoda e nociva", como dito. Não apenas a categoria mais apta ao crime, como também ao recrutamento pelas forças da ordem. Percebe-se que predomina em Caio Prado, em relação a esta terceira categoria de desclassificados, visão similar àquela de Marx em relação ao lumpem, pois, para o historiador brasileiro seriam eles facilmente recrutados pelos poderosos e mandões locais, servindo na luta entre famílias ou recrutados pelas facções políticas em luta no período da Independência. Esta visão de Caio Prado reflete uma visão predominante na esquerda brasileira, que constituiu um verdadeiro horror político a este tipo de desclassificado social.

Todo este quadro estruturado no período colonial irá se complicar enormemente na segunda metade do século XIX, no processo de transição do trabalho escravo para o trabalho livre. Em função do dinamismo próprio às economias agroexportadoras, que cresciam em extensão e não mediante a incorporação de novas técnicas, dois fatores se mostravam primordiais ao seu crescimento mediante as conjunturas favoráveis: disponibilidade de terras e mão-de-obra. Quanto ao primeiro fator, ele não se mostrou em nenhum ponto limitativo até o fim do século XIX no estado de São Paulo. Contudo, o mesmo não pode ser dito do segundo fator.

Desde a primeira metade do século XIX, as pressões sobre o tráfico de escravos intensificaram-se consideravelmente. Já em I8I5, o Governo Britânico proibiu o tráfico ao norte do equador - o que afetava a principal fonte de fornecimento de escravos para o Brasil - sem obter contudo sucesso. Em I826, a Inglaterra negocia o reconhecimento da Independência do Brasil mediante compromisso do governo brasileiro em acabar com o tráfico até I830, mas sem obter resultados significativos. Uma nova tentativa foi feita em I845, com a chamada lei Bill Aberdeen, que declarava lícito o apresamento de qualquer embarcação empregada no tráfico de escravos. Mas somente em I850, com a Lei 58I, que o tráfico de escravos para o Brasil é definitivamente abolido.

Com a abolição do tráfico e as leis que se seguem - Lei do Ventre Livre, I871, e Lei dos Sexagenários, I885 - bem como o crescimento da propaganda abolicionista e da pressão exercida pelos próprios escravos, o que observaremos a seguir é um forte e irreversível descenso da população escrava em todo o país. Para as regiões que se expandiam economicamente, contudo, como era o caso das zonas cafeeiras de São Paulo, vamos observar, ao menos no início, o exato oposto, isto é, um crescimento da população escrava (CONRAD, 1975). Isto porque com os altos preços dos escravos no mercado, regiões açucareiras decadentes, mormente o Nordeste, passam a liquidar seus escravos, 
transferindo-os para o Sudeste, principalmente São Paulo. Trata-se do conhecido tráfico interprovincial. Solução temporária, como veremos, porque todos sabiam ou sentiam que o fim da escravidão era apenas uma questão de tempo.

Como obter mão-de-obra, então? Duas eram as alternativas que se apresentavam à época: a oferta interna de mão-de-obra, via setor de subsistência ou população urbana ociosa; a vinda de imigrantes. As escolhas, os motivos e as dificuldades que cercam uma ou outra das opções é história que convém analisar mais de perto, uma vez que ela está estreitamente relacionada às tendências criminais e punitivas do período estudado.

Uma questão muito importante que se apresentava à época na opinião pública era a da suposta carência de braços para lavoura e, por conseguinte, a necessidade do combate à vadiagem. Existe um argumento tradicional na historiografia da escravidão, que reitera a posição de parte dos fazendeiros na época, segundo a qual o trabalhador nacional era encarado como vadio, carga inútil, desclassificado para o trabalho. E em função disso, a saída para o problema da mão-de-obra seria a imigração. Segundo este ponto de vista, quem não havia sido senhor nem escravo, os homens pobres e livres, não havia passado pela escola do trabalho e, por isso, trabalhar para alguém se apresentava como a forma mais aviltada de existência. Em outras palavras, a forma como os senhores se acostumaram a lidar com o escravo, não teria afetado apenas sua percepção do trabalho, como também a dos próprios desocupados ou trabalhadores potenciais. Daí o apelo à imigração (KOWARICK, 1994).

Se aceitarmos os números apresentados por Joaquim Floriano de Godói no jornal $A$ Província de S. Paulo, em I875, tenderemos a concluir, de fato, que a mão-de-obra nacional era insuficiente para conformar um exército de reserva ${ }^{2}$. Os braços livres empregados na lavora era da ordem de 252.579 trabalhadores; os braços escravos da ordem de 90.6I2; e os braços livres válidos e desocupados da ordem de 308.58I, isto é, menos do que o total empregado (GUIMARÃES, 2008). Apesar de os números relativos ao uso de trabalhadores livres não estarem discriminados, é de se supor que eles sejam em sua maioria relativos aos nacionais, uma vez que a imigração neste momento era ainda bastante tímida.

É bem verdade que o fato de os fazendeiros do café estarem acostumados a tratar trabalhadores como escravos representou uma severa dificuldade ao processo de transição para o trabalho livre. Isto pode ser atestado nas constantes queixas e até revoltas de imigrantes, como a da fazenda Ibicaba, em Rio Claro. Contudo, dizer que os homens livres não estavam dispostos ao trabalho é algo temerário. Um argumento bastante conhecido e

\footnotetext{
${ }^{2}$ Este é o ponto de vista de Alberto Passos Guimarães (2008).
} 
contrário a este ponto de vista é o defendido por Ademir Gebara, segundo o qual os escravos fugiam com seus instrumentos de trabalho, o que denotaria estarem em busca de uma possibilidade de vender seu trabalho para outros fazendeiros (GEBARA, I986). Mas pode ser também que apenas estivessem dispostos a não abrir mão da única coisa que possuíam, seus instrumentos de trabalho, bem como da possibilidade de virem a empregalos em seu benefício próprio.

Neste sentido, várias pesquisas mostraram que o projeto imigrantista paulista foi exceção no Brasil. Mas mesmo dentro do chamado Oeste Paulista, há diferenças consideráveis. Um exemplo, entre outros: a colônia Santa Bárbara, em Limeira, do senador Francisco Antonio de Souza Queiros, que tinha 208 nacionais livres trabalhando nas suas lavouras (MOURA, 20IO, p. 288-290).

Um ponto de vista mais convincente é o de que a alegada inadequação da mão-deobra nacional ao trabalho na lavoura e o vício que a acompanha, a vadiagem, compunha uma ideologia forjada pelos cafeicultores de São Paulo a fim de, por um lado, espicharem a escravidão até o limite do suportável, e, por outro, favorecer uma política imigrantista. Mas a questão permanece: por que o imigrante e não o trabalhador nacional?

Já vimos que, segundo os dados apresentados, a mão de obra livre nacional existente era insuficiente para conformar um exército de reserva. Mas foi sem dúvida o imaginário construído a partir do medo e da insegurança "suscitada pelos conflitos reais ou simplesmente potenciais entre uma diminuta elite" composta por grandes proprietários, bem como pelas camadas médias urbanas e "uma massa de gente miserável - escravos e livres" (AZEVEDO, 2004, p. 26), que apontou para a tendência a se desenhar no processo de formação do mercado de trabalho no Brasil.

Segundo Célia Maria Marinho de Azevedo, tendeu a generalizar no Brasil, depois de I804, o "grande medo" suscitado pela revolução de São Domingos, no Haiti, quando os negros se rebelaram contra a escravidão e proclamaram sua independência. As três primeiras décadas do século XIX só viriam reforçar este medo, com o desenrolar das insurreições baianas, organizadas pelos haussás e nagôs. Medo de inversão da ordem social e política, da vingança generalizada contra os brancos (AZEVEDO, 2004). Trata-se aqui da lógica já apontada anteriormente do inimigo interno, de uma massa de pessoas perigosas (corpo estranho à nação, como dizia Caio Prado Jr).

Reflexo deste medo são as propostas de abolição gradual, complementadas, em algumas delas, com a imigração de trabalhadores europeus. Haviam até aqueles que defendiam a devolução dos negros à África. Esta perspectiva seria reforçada, na segunda metade do século XIX, pela teorias raciais. A questão passa a ser, então, não tanto se livrar 
dos negros (ou dos pobres), mas substitui-los por europeus. Mas aí fica a questão do que fazer com eles. Para aqueles que achavam ser possível incorporar (ao invés de deportar) os negros após a abolição, a questão passava a ser a de políticas públicas voltadas para tornar ocupados os desocupados, isto é, um sistemático combate à "vagabundagem". O negro perigoso devia ser rapidamente incorporado à sociedade via estratégias disciplinares (AZEVEDO, 2004, p. 34-48).

Este medo voltou a se colocar com toda a força na segunda metade do século XIX, quando começaram a entrar em São Paulo muitos imigrantes negros do Nordeste. Jornais como A Província de São Paulo falam em uma “onda negra" perigosa, a ameaçar a sociedade paulistana. Trata-se do temor generalizado suscitado pela multidão de escravos transportados do norte para o sul. Os parlamentares diziam que esta região estava recebendo grande quantidade de negros criminosos que viriam "perturbar a paz do lar doméstico e conservar em constante alarma e sobressalto as famílias". Discutia-se, em particular, o aumento do número de crimes cometidos pelos escravos contra seus senhores, feitores e familiares. É neste preciso sentido que os parlamentares votaram o projeto de lei (que se tornou lei em I88I) que aumentava os impostos sobre cativos trazidos para São Paulo. A partir disso, a imigração parecia ser o único caminho possível (AZEVEDO, 2004, pp. 96-IOI).

Mas esta visão imigrantista estava longe de ser uma unanimidade. Havia deputados que igualmente se opunham aos imigrantes, por considera-los também perigosos e "perturbadores da paz pública". Mas apesar desta antipatia despertada pelos imigrantes em muitos políticos e proprietários em fins da década de i870, o temor em relação aos escravos era bem maior. Tudo isso revela que eles queriam resolver o problema da mão-de-obra, mas também que o desejo de ordem era maior que tudo

Os que eram a favor do uso do trabalhador livre nacional, defendiam a votação de leis que obrigassem ao trabalho; em caso de recusa, de acordo com o projeto do deputado Manoel Pereira de Souza Arouca, em I874, o agregado seria punido com 3 dias de prisão por cada dia de falta. Muitos defendiam também uma lei que isentasse do serviço ativo da Guarda Nacional e do recrutamento todos os indivíduos empregados na lavoura (AZEVEDO, 2004).

Segundo esta ótica, além de aumentar o número de braços dispostos para a lavoura, tais medidas também diminuiriam os crimes, pois "os ociosos, vendo-se obrigados a procurar trabalho, deixariam de ser matéria disposta para o crime" (AZEVEDO, 2004, p. II3). Outra medida foi a criação em I874 do Instituto de Educandos Artífices, cuja proposta 
era internar "meninos desvalidos" a fim de "educa-los para o trabalho". Tratam-se de estratégias disciplinares de controle do trabalho no dealbar do trabalho livre no Brasil.

Mas estes mecanismos de controle sobre o trabalho acabavam por servir de desincentivo ao trabalho nas fazendas. Além disso, o trabalho nas ferrovias parecia mais atrativo a estes homens livres, possivelmente por pagar melhor aos trabalhadores. Neste sentido, a vinda de imigrantes parecia oferecer uma vantagem sobre o uso da mão-de-obra nacional: iria aumentar a massa de trabalhadores disponíveis e com isso baixar os salários, conformando um verdadeiro exército de reserva.

Em resumo, o tema da ociosidade ou da vadiagem do nacional era ideológico e encobria ao menos 3 questões: a não-submissão do nacional pobre a um tempo capitalista, excedente às suas necessidades de sobrevivência; o arbítrio dos governantes (recrutamento forçado) a entravar a própria possibilidade de disciplina do trabalho livre; altos salários exigidos pela mão-de-obra nacional.

\section{Tendências criminais e punitivas no Estado de São Paulo, século XIX}

Logo após a proibição do tráfico de escravos no Brasil, em sua passagem por São Paulo, em I85I, o naturalista Auguste de Saint-Hilaire parecia intuir a tendência que começava a esboçar-se no par crime/punição no país. Dizia ele que os crimes contra a pessoa, tais como homicídios e agressões, seriam os mais comuns no Brasil à época (SAINT-HILAIRE, I976, p. 78). Tal afirmação parece estar de acordo com os dados apresentados por Daniel Pedro Müller, em I837:

\section{Quadro I: “Crimes” do interior de São Paulo, I836}

\begin{tabular}{|l|l|}
\hline Crimes & Ocorrência \\
\hline Homicídio & 98 \\
\hline Tentativa de homicídio & IO \\
\hline Ferimento & 92 \\
\hline Ofensas físicas & I7 \\
\hline Roubo & 55 \\
\hline Contrabando de escravos & 2 \\
\hline Moeda falsa & I \\
\hline Prevaricação & I \\
\hline Adultério & 5 \\
\hline Estupro & 3 \\
\hline Dar coito a escravos & I \\
\hline Poligamia & I \\
\hline
\end{tabular}

Fonte: MÜLLER, I837 
Os dados referem-se apenas às cidades do interior da província, sendo por isso de se esperar que a inclusão dos registros relativos à capital elevem consideravelmente os crimes em todo o estado. Em seu discurso de abertura da sessão legislativa da província de São Paulo, em I5 de abril de I850, o presidente provincial Vicente Pires da Motta, baseando-se em relatório do chefe de polícia do ano anterior, parece endossar o mesmo ponto de vista: "Não são raros os delitos contra a propriedade mas as frequências das violências contra as pessoas assusta”. Segundo ele, em I849 foram 58 processos de morte e 43 de ferimentos e ofensas físicas; mas fala de vários outros crimes cujos réus ainda não compareceram em juízo ou não foram processados. Trata-se aqui de dados relativos à capital.

Cabe uma observação a respeito deste tipo de estatística na época do Império no Brasil. Os dados de Daniel Pedro Müller não permitem discriminar crimes cometidos, registro de ocorrências, prisões efetivas e condenações judiciais. Primeiramente, a precariedade da polícia no Império, atestada pelos chefes de polícia em inúmeros relatórios, tornava muito difícil o acompanhamento das ocorrências em tempo real. É razoável supor que muitos crimes, sobretudo aqueles do meio rural, sequer chegavam ao conhecimento da polícia. Depois, conforme ainda a queixa de vários chefes de polícia da província ao longo do século XIX, muitos delegados não faziam o registro adequado dos crimes e tampouco os enviava, quando solicitado, aos chefes de polícia. Além disso, o número de autos registrados quase nunca coincide com o número de prisões efetivadas, uma vez que as fugas se mostravam bastante frequentes. Por fim, das pessoas presas, apenas uma pequena parte era efetivamente condenada e vinha a cumprir pena nas prisões.

Mas a discrepância entre o número de processos apresentado pelo presidente de província e os dados apresentados por Daniel Pedro Müller, I2 anos antes, obrigam-nos a especular a respeito da relação entre crime e punição no contexto da época. Dizia SaintHilaire, com certa estranheza, em relação aos padrões franceses da época, que os brasileiros pareciam nutrir uma "grande paixão pelos criminosos". "Não há uma única pessoa, nas camadas inferiores da sociedade, que não seja capaz de ajudar de bom grado um criminoso a escapar das mãos da justiça" (SAINT-HILAIRE, I976, p. 78). O resultado, segundo ele, seria uma tendência geral à "impunidade”. Para Vicente Pires da Motta, a "impunidade" tiraria aos "malvados" o "medo do castigo".

Sérgio Buarque de Holanda já havia assinalado em 1936, em obra já clássica, este "traço definido do caráter brasileiro", a "cordialidade", não no sentido comumente propalado dentro como fora do país, de "boas maneiras", "civilidade”, "polidez". "Nossa forma ordinária de convívio social é, no fundo, justamente o contrário da polidez", 
precisamente, o contrário daquilo que Norbert Elias chamou de "processo civilizador", cujo traço mais característico é o do controle dos afetos. Convívio este ditado por uma ética de fundo emotivo, própria aos círculos familiares, à intimidade privada. Em outras palavras, horror às distâncias, às formalidades da lei, eis o traço definidor do espírito brasileiro, segundo Sérgio Buarque de Holanda (1995).

Maria Silvia de Carvalho Franco defende a tese segundo a qual a violência era algo ingente à relação comunitária. Envolve geralmente pessoas que mantêm relações amistosas (relações de parentesco e amizade) e irrompem a partir de eventos os mais banais. Esta violência corresponderia a todo um sistema de valores centrados na coragem pessoal e na defesa da honra e seria socialmente válido (FRANCO, 1983). Aqui cabem duas observações. Primeiro, a autora está pensando o meio rural, onde não só a atuação da polícia é mais episódica como também as possibilidades de ocultação de um crime são maiores. Depois, nem todos os crimes contra a pessoa são propriamente crimes em defesa da honra. Mas inegavelmente, parece que tais crimes tendiam a ser mais tolerados pela população do que os crimes contra a propriedade. Isto leva a crer, portanto, que os efetivos de crimes cometidos eram bem maiores do que aqueles indicados seja pelos inquéritos, seja pelas prisões, seja pelos processos.

Mas o que se observa com toda clareza ao longo do século XIX é que tais números relativos aos crimes contra a pessoa tendem a se manter superiores aos demais tipos de crimes, apesar de não registrarem aumento significativo ao longo dos anos. A partir deste momento começa a se estabelecer um esforço de classificar os crimes em dois tipos principais, os "particulares" e os "públicos". Os dois problemas maiores daquilo que se considerava "segurança pública" neste momento eram as rebeliões e as fugas de presos ou de escravos. E nenhum dos dois problemas se apresentava de fato como um problema entre as anos I850 e I860. De fato, por um lado, a última rebelião do ciclo de rebeliões que se inicia no período regencial, a Praieira, liderada por grandes proprietários de terra de Pernambuco, já havia sido pacificada (CARVALHO, 1996). Por outro, as rebeliões, bem como as fugas de escravos, só se tornariam uma "ameaça pública" a partir dos anos I870/I880, quando a pressão abolicionista aumenta. Então, de fato, o grande problema de segurança eram os "crimes particulares", conforme mostra o quadro a seguir.

Quadro 2: Crimes cometidos entre I858 e I864 na província de São Paulo

\begin{tabular}{|l|l|l|l|l|l|l|l|}
\hline Crimes & I858 & I859 & I860 & I86I & I862 & I863 & I864 \\
\hline Homicídios & 36 & I9 & 26 & 27 & 43 & $3 \mathrm{I}$ & 52 \\
\hline Tentativa de homicídio & 7 & I9 & 5 & 8 & 7 & 5 & I5 \\
\hline
\end{tabular}




\begin{tabular}{|l|l|l|l|l|l|l|l|}
\hline Ferimentos e ofensas f. & I63 & I3I & III & 57 & 69 & 82 & I48 \\
\hline Furto & 7 & 6 & 5 & 7 & 5 & 6 & I8 \\
\hline Roubo & II & 7 & 4 & IO & 3 & 7 & I3 \\
\hline Insurreição & & & & & & & I \\
\hline
\end{tabular}

Fonte: SOARES, I865

O próprio autor destes dados, o presidente de província João Crispiniano Soares reconhece estar "muito longe de acreditar que o quadro apresentado seja a expressão da realidade" (SOARES, I865, p. 8). Isto é, os dados não permitem avaliar o real crescimento ou decrescimento dos delitos. Mas, segundo o autor, dá para ver que "a segurança individual piorou". Todavia, se compararmos com os dados de I836, veremos que o número total de crimes contra a pessoa diminuiu significativamente, mormente se considerarmos que os dados de 1836 referiam-se apenas ao interior, enquanto os de 1865 referem-se à toda a província. Apesar de que, como veremos a seguir, alguns anos depois, em I869, os crimes contra a pessoa terem observado um ligeiro aumento no total.

Então por que insistir na ideia de "insegurança individual"? É razoável supor que os crimes cometidos por escravos, particularmente aqueles impetrados contra seu senhor e dependentes, estavam tendencialmente aumentando no período pós abolição do tráfico. E, neste sentido, eles acompanhavam a paranoia pública de uma vingança negra generalizada. O quadro a seguir permite-nos ter uma ideia mais clara da situação.

Quadro 3: Presos existentes nas cadeias da província de S. Paulo em I870

\begin{tabular}{|l|l|l|l|}
\hline Crime & Livre & Escravo & Pena \\
\hline Homicídio & 2 & $\mathbf{2 2}$ & Morte \\
\hline Homicídio & 44 & 75 & Galés perpétua \\
\hline Roubo com violência & IO & I & Galés temporária \\
\hline Homicídio & 7 & o & Galés temporária \\
\hline Homicídio & 5 & I & Prisão perpétua \\
\hline Homicídio & 20 & o & Prisão por tempo \\
\hline Vários crimes (menos hom.) & 23 & o & Prisão por tempo \\
\hline
\end{tabular}

Fonte: SILVA, I87I

Primeiramente, os números mostram a ligeira superioridade dos crimes contra a pessoa cometidos por escravos, 97 ao todo, contra 86 cometidos por pessoas livres. A diferença, contudo, deve ser bem maior, uma vez que os sentenciados a morte tinham sua pena, via de regra, comutada a pena de galés e, neste caso, muitos presos eram transferidos para o presídio de Fernando de Noronha. Por outro lado, os números mostram que havia certa diferença entre as penas referidas a escravos e homens livres. De um total de 24 homicídios, apenas dois homens livres foram condenados a morte, contra 22 escravos. $\mathrm{O}$ mesmo se observa em relação às penas de galés perpétua. 
Os dados parecem estar em desacordo com a pesquisa recente de Ricardo Alexandre Ferreira, para quem, não haveria qualquer distinção punitiva em relação a livres, libertos e escravos. De fato, como veremos a seguir, é inegável que durante a fase de processo, livres e escravos podiam ficar presos por dias ou meses nas mesmas condições, dividindo o mesmo espaço até a conclusão dos processos, que podiam se arrastar por meses (FERREIRA, 2009, p. I8I). Contudo, a partir das condenações diferenciadas, como mostra o quadro acima, a hipótese de uma seletividade penal, nascida a partir do desejo de ordem do período, parece bastante plausível.

É bem verdade também que não existiu no Brasil um Código Negro, como existiu nas colônias francesas, para tratar da relação entre senhores e escravos. A legislação a respeito dos escravos e também dos libertos encontrava-se "dispersa pelos códigos legais e na forma de cartas de lei, posturas municipais, alvarás, decisões, decretos, avisos, aditamentos, regulamentos e leis excepcionais" (FERREIRA, 2009, p. I83). Por isso mesmo que a escravidão foi por muito tempo, mesmo depois de sua extinção formal, o nó da cidadania, a obstacularizar a formatação de um código civil. Mas isto não impediu que os juízes municipais tratassem de forma diferenciada escravos e livres. Esta zona de indefinição jurídica a que os escravos foram relegados, acabavam por deixar aberto um enorme flanco para as ações punitivas contra eles impetradas, que muitas vezes resumia-se às diferentes formas de violência praticadas por seus senhores.

Um outro conjunto de dados apresentado pelo presidente de província Antonio da Costa Pinto Silva revela uma diferença significativa entre o número de crimes cometidos em I870 e o número de prisões efetuadas. No total foram 255 crimes contra a pessoa contra I5I prisões efetuadas. Contudo, se olharmos para o número de roubos a discrepância é ainda maior, I2 contra I. É razoável supor a partir daí que a tolerância em relação aos crimes contra a propriedade, que ainda não eram considerados um problema de segurança nesta época, era bem maior do que em relação aos crimes contra a pessoa. Mas mostram também uma outra coisa muito importante: o esforço do Estado brasileiro, em processo de estruturação no segundo reinado (CARVALHO, 1996), no sentido de assegurar para si o monopólio da violência.

Segundo o mesmo presidente de província, entre as causas dos crimes de homicídio mais comuns estão: "embriaguez", "jogo e mulher" e "litígios de terras". Nestes casos, duas eram as razões principais dos réus fugirem à condenação: "condescendência do júri" e "facilidade que encontram os réus em escapar à ação da justiça”. Para o ministro Eusébio Queiroz Mattoso, os "receios das vinganças dos criminosos" era o principal motivo da "condescendência do júri". Segundo ele, também, o grande problema era o "asilo" que 
davam os proprietários de terras aos "grandes criminosos" (CAMARA, I85I, p. 5). Mas segundo Saint-Hilaire, também era motivo a naturalidade com que se encaravam tais crimes no Brasil, mormente os de honra. Um caso emblemático se deu no dia 24 de julho, na cidade de Pindamonhangaba, quando Francisco Ferreira assassinou a sua mulher e feriu gravemente Bento José da Costa, suposto amante. Ferreira apresentou-se à autoridade, confessou o crime e no ato do julgamento procurou justifica-lo. Foi absolvido, o juiz apelou da decisão do júri, mas no fim não foi condenado.

Mas os dados de 1870 mostram ainda uma outra coisa muito importante, a apontar para uma nova tendência: o aumento da repressão aos "crimes de pequena intensidade, porém muito frequentes e quase sempre precursores de crimes grandes", tais como jogo, embriaguez e vadiagem (SILVA, I87, p. 2). Esta tendência tem a ver certamente com este movimento de crescimento do Estado policial no segundo reinado, mas tem a ver também, certamente, com o que está acontecendo na economia. E para entender o que está acontecendo na economia é preciso entender o que está acontecendo com os métodos punitivos.

Primeiramente, qual era a situação das cadeias por esta época na província de São Paulo? Em I870, São Paulo contava com uma casa de correção, 36 cadeias e 26 casas de detenção. A casa de correção começou a ser construída em I838, mas só foi concluída em I852. Desde esta data até I87I, o movimento de presos foi o seguinte: entraram 540 homens e 45 mulheres; foram postos em liberdade 222 homens e 2I mulheres; faleceram 69 homens; foram removidos I09 homens e 8 mulheres; e, assim, existiam em I87I I4I homens e I5 mulheres (SILVA, I87I, p. I4). Estes números mostram várias coisas. Primeiro, que a população carcerária era composta nesta época predominantemente por pessoas do sexo masculino. Depois, o alarmante número de mortos nas prisões, que provavelmente se devia à superlotação e às péssimas condições de higiene, atestadas pelo próprio presidente de província Antonio da Costa Pinto Silva. Por fim, que não havia separação entre presos do sexo masculino e feminino. Além disso, conforme nos informa nosso autor, homens livres à espera de julgamento, dividiam o espaço das casas de detenção com escravos, bem como "o moço inexperiente com o assassino de profissão" (SILVA, I87I, p. II).

Assim, o presidente de província aponta para a necessidade de uma série de reformas a serem feitas e que efetivamente seriam feitas ao longo da segunda metade do século XIX. Primeiramente, uma rigorosa classificação dos presos, a fim de separá-los ou isolá-los de acordo com o seu tipo criminal. A mais urgente reforma, segundo seu ponto de vista, seria construir prisões celulares separadas para as mulheres, apesar de reconhecer a dificuldade de se aplicar tal regime às mulheres, visto que "são mais resistentes ao 
isolamento" (SILVA, I87I, p. I3). Uma outra reforma urgente era a remoção para Fernando de Noronha dos condenados a galés, que eram em sua esmagadora maioria, como visto, escravos. Por fim, havia a necessidade de construir mais prisões, tendo em vista não apenas o aumento ano a ano do número de presos na província como também a total inadequação das cadeias da província, em geral casas adaptadas (SILVA, I87I, p. I5).

Para um controle mais rigoroso dos presos, segundo o desejo de ordem da época, havia ainda a necessidade de organizar uma estatística regular, bem como um "livro de culpados", pois sem ele não seria possível saber quantos réus estavam fugidos da justiça. Segundo um livro organizado pelo secretario de polícia da província, haveria um total 2.00o réus foragidos, número muitíssimo superior àquele de presos existente, processados e não processados (SILVA, I87I).

Mas qual era, afinal, o papel da prisão neste momento na província de São Paulo? O regime adotado na penitenciária de São Paulo desde a sua inauguração em I852 era o de Auburn, isto é, isolamento celular noturno com trabalho coletivo durante o dia. Eram ao todo 7 oficinas de trabalho. A função do trabalho aí, nas palavras do próprio presidente de província, não era tanto econômica, mas moral, na medida em que pretendia "habituar o corpo ao trabalho". Segundo ele, poucos eram os condenados que voltavam à penitenciária para cumprirem pena. "Estes são só os condenados por atentados contra a propriedade". A causa seria, segundo ele, a miséria reinante na província (SILVA, I87I, p. II). De fato, o balanço financeiro da penitenciária nos anos de i864 e I870 mostra haver um permanente déficit orçamentário:

Quadro 4: Balanço financeiro da casa de correção de São Paulo, I864 e I870

\begin{tabular}{|l|l|l|l|}
\hline Ano & Receita & Despesa & Défict \\
\hline $\mathrm{I} 864$ & $\mathrm{I} 3: 447$ \$940 & $38: 6 \mathrm{I} 7$ \$402 & $25: 169 \$ 462$ \\
\hline $\mathrm{I} 870$ & $\mathrm{I} 7: 649 \$ 700$ & $5 \mathrm{I}: 805 \$ 066$ & $34: \mathrm{I} 55 \$ 366$ \\
\hline
\end{tabular}

Fonte: SOARES, I865; SILVA, I87I

Este balanço mostra que houve expansão considerável da produção em 6 anos, mas também aumentaram muito os custos com os presos, provavelmente em função do aumento de seu efetivo, que foi da ordem de 38 presos ao todo. A diferença era coberta pelo Estado. Ou seja, sem sombra de dúvida o propósito do trabalho na cadeia não era nem o lucro e nem tão pouco o controle do mercado de trabalho, mas sim o disciplinamento do trabalho nas condições pré-capitalistas do Brasil da época. Esta perspectiva se mostrava tão mais realista à medida que o cativeiro chegava ao fim e as elites cafeeiras não sabiam ainda ao certo o que fazer com a organização do trabalho livre. 
Voltamos neste ponto, então, à discussão sobre as dificuldades encontradas pelas elites escravocratas e o Estado em relação à transição para o trabalho livre. Como visto, houve um grande aumento do número de crimes de sangue na década de i870, sobretudo em função do aumento dos crimes de escravos contra seus senhores. Nestes casos, ao invés de fugirem, os escravos apresentavam-se espontaneamente à polícia, mostrando com isso que preferiam a cadeia ou as galés ao cativeiro. Isto é, em uma ordem escravocrata prisão não tinha o significado de privação de liberdade, antes o contrário. E por isso mesmo não se constituíam em método punitivo exemplar.

O livro V das Ordenações Filipinas, que entraram em vigor em I603, funcionava como Código Penal, somente criado no Brasil em I830. Nelas não há nenhuma pena que corresponda somente à prisão, apesar de haver tanto em Portugal quanto no Brasil edificações destinadas a este fim. Seu papel era, principalmente, abrigar aqueles que aguardavam decisões judiciais. As penas definidas nas Ordenações eram as seguintes: degredos, espancamentos, marcações com ferro em brasa e a pena de morte (para crimes mais graves). "Havia ainda uma lei específica para a punição exemplar dos escravos que atentassem contra a vida de seus senhores. O título 4I dispunha que, antes de ser executado (...) o escravo (...) teria suas carnes apertadas por tenazes ardentes e as mãos decepadas" (FERREIRA, 2009, p. I87).

A Constituição de I824 não continha também nenhuma regra para a definição jurídica do escravo. E o Código Penal do Império, definido em tempo recorde, guardava ambiguidades semelhantes às Ordenações Filipinas em relação à situação jurídica do escravo. De acordo com ele, nos casos mais graves, penas de morte ou galés perpétuas; em casos menos graves, penas de prisão eram geralmente substituídas pela de açoites (a pena de açoites só foi abolida em I886). Mas não havia qualquer detalhamento quanto à forma de imputar pena aos escravos. Apesar de depois de I835, após a reforma do Código, não caber mais recursos nos casos de assassinatos de senhores, a comutação da pena de morte em pena de galés pelo Poder Moderador tornou-se uma prática na segunda metade do século XIX, apos o fim do tráfico, em função da pressão exercida pelos proprietários de escravos, temerosos de perderem sua principal força de trabalho. Em suma, a manutenção do cativeiro impôs uma situação de exceção perante o sistema criminal existente no Brasil.

Perante esta situação, uma solução encontrada pelo Júri ou pelos próprios fazendeiros, foi converter a pena de galés em açoites. Outro ajustamento oficioso eram os linchamentos (isto é, o escravo matava e em seguida se apresentava às autoridades policiais; os populares arrancavam-no da prisão e o matavam a pedradas e pauladas) (AZEVEDO, 2004, p. I72). Isto mostrava mais uma vez que no Brasil havia uma certa 
tendência de o sentimento pessoal de vingança se sobrepor à lei, como já havia mostrado Sérgio Buarque de Holanda em seu clássico Raízes do Brasil (1995).

$\mathrm{Na}$ década de I880 aumentam os números de revoltas e fugas em massa. Há relatos de escravos enfrentando a polícia nas ruas da capital e várias outras cidades importantes da província. "A grande questão debatida tão longamente durante todo o século XIX - o que fazer com o negro livre (...) - estava a exigir agora uma premente resposta" (AZEVEDO, 2004, p. 179). A preocupação generalizada, mesmo entre abolicionistas, era garantir a ordem e a propriedade. Daí que os crimes contra a pessoa tenham sido cercado de tantos cuidados por parte das forças constituídas.

Os dados aqui analisados vão de encontro ao estudo realizado por Silvia Hunold Lara para o Rio de Janeiro. Segundo a autora, a presença escrava (seja enquanto réu, seja enquanto vítima) é maior em crimes de morte do que em crimes de ferimentos e furtos. Suas vítimas eram sobretudo não escravos. No período estudado, primeira metade do século XIX, eram raros os casos de vítimas serem os senhores. Isto não quer dizer que não havia crimes contra senhores, mas que não viraram processo judicial. Isto é, o controle social do escravo não era papel do Estado mas do próprio senhor. Na segunda metade do século XIX, no entanto, a tendência será inversa: aumenta consideravelmente o número de processos de assassinatos de senhores por seus escravos, mostrando uma crescente intervenção do Estado no controle social, em contraposição ao controle exercido essencialmente a partir de relações pessoais de dominação (LARA, I988, pp. 273-282).

Contudo, no período final da escravidão, uma nova tendência começa a se esboçar. Primeiramente, começa a haver uma diminuição dos crimes contra a pessoa. Para o ano de I884 foram ao todo 186 crimes do tipo homicídio e ferimentos e ofensas físicas. Deste total, cerca de metade foi transformada em processo e apenas metade destes foi efetivamente julgado por juízes municipais, conforme nos informa o presidente da província de São Paulo, José Luiz de Almeida Couto, em I885. Isto se deve provavelmente ao fato de que a estratégia de resistência escrava passou do assassinato de seus senhores para as fugas em massa. De fato, segundo o mesmo relatório, o número de fugas das cadeias, bem como as "insurreições" e "turbações da ordem" cresceram consideravelmente. Mas o que mais chama a atenção é o aumento da repressão aos pequenos delitos, que antes apareciam apenas sob forma de discretas preocupações dos chefes de polícia.

Quadro 5: Presos em custodia nas diversas cadeias da capital em I884

\begin{tabular}{|l|l|}
\hline Delito & Ocorrência \\
\hline Embriaguez & $69 \mathrm{I}$ \\
\hline
\end{tabular}




\begin{tabular}{|l|l|}
\hline Por motivos diversos & $59 \mathrm{I}$ \\
\hline Alienados & 23 \\
\hline
\end{tabular}

Fonte: COUTO, I885

Dos julgamentos de termos de bem viver, no mesmo ano, envolvendo as infrações penais de vadiagem, embriaguez, prostituição e turbação da ordem, 91\% resultaram em condenação dos réus. Deste total de condenados, 90\% eram constituídos por brasileiros, homens maiores de idade e sem profissão definida (COUTO, I885, p. II4). Ora, não é razoável supor que o propósito aqui fosse forjar um exército industrial de reserva neste momento em que a escravidão estava a dar seus últimos suspiros. Isto porque, como já foi suficientemente mostrado por vários estudos, a esmagadora maioria da força de trabalho no campo ou na cidade, no dealbar do processo de industrialização do Brasil, era composta de estrangeiros, graças à imigração em massa para o Brasil a partir de I884. A questão era, então, o que fazer com esta massa enorme de desempregados ou subempregados, exescravos ou não, que vinham engrossar o fosso enorme existente entre os bem classificados desta ordem social excludente e os desclassificados, isto é, os homens pobres e livres?

Segundo a tese conhecida de Florestan Fernandes, o ex-escravo foi entregue a sua própria sorte, sem estar preparado para a sociedade de mercado que se formava (FERNANDES, 1978, p. I5). Tinham de optar, assim, "entre a reabsorção no sistema de produção, em condições substancialmente análogas às anteriores, e a degradação de sua situação econômica, incorporando-se à massa de desocupados e de semi-ocupados da economia de subsistência do lugar ou de outra região" (FERNANDES, 1978, p. I7). Em outras palavras, diante do ex-escravo abriam-se duas escolhas: "Vedado o caminho da classificação econômica e social pela proletarização, restava-lhes aceitar a incorporação gradual à escória do operariado urbano em crescimento ou abater-se penosamente, procurando no ócio dissimulado, na vagabundagem sistemática ou na criminalidade fortuita meios para salvar as aparências e a dignidade de homem livre" (FERNANDES, I978, p. 28).

Cria-se assim, em torno dos ex-escravos, que vêm engrossar a fileira dos desclassificados da ordem econômica pós-colonial, um clima de suspeição generalizada, que cria vários estereótipos para esta camada da população: vagabundo, desordeiro, cachaceiro, etc. Já não aparecia como o inimigo da ordem, porque conspirasse pela liberdade; mas como uma ameaça à propriedade e à segurança das pessoas.

É neste preciso momento da história do estado que a pena de prisão passa a ter de fato algum significado histórico. Em outras palavras, é no contexto do aumento do refugo do exército de reserva, em função do aumento de uma massa enorme de pessoas que têm 
escassas possibilidades de serem absorvidas pelo mercado de trabalho - composta sobretudo de ex-escravos e homens pobres e livres - que se explica o aumento do encarceramento como estratégia disciplinar no final do século XIX.

O resultado disso foi um aumento considerável da população carcerária no período final da escravidão. Se desde sua fundação em I852 até I87I, isto é, em I9 anos havia entrado para a casa de correção 540 homens e 45 mulheres, estes número saltaram para I.I77 e I32 em I884. Espantoso igualmente é o número de mortos nestes 32 anos de existência da penitenciária, 248 mortos. O chefe de polícia da província calculou uma taxa de mortalidade em torno de $2 \mathrm{I} \%$ (COUTO, I885). Isto é, segundo estes dados as condições das prisões no Brasil em finais do século XIX haviam piorado consideravelmente. Isto porque agora a prisão já não podia mais significar uma possibilidade de libertação. Tinha por isso que significar o seu exato oposto.

\section{Considerações finais}

Como argumentou Francisco de Oliveira em mais de uma oportunidade, o subdesenvolvimento foi a forma da exceção permanente do sistema capitalista na sua periferia (OLIVEIRA, 20I3; OLIVEIRA, 2007). Exceção sobre os oprimidos: escravidão como exceção da mercadoria, desperdício de trabalho como exceção do aumento de produtividade, precariedade como exceção do trabalho regular das fábricas, dependência como exceção à autonomia da pessoa, casuísmos de todo tipo como exceção à universalidade da lei, etc. Oprimidos aqui entendidos como todos os sobreviventes da catástrofe colonial: índios, escravos, ex-escravos, homens pobres e livres de todo tipo tapuias, caboclos, quilombolas... Oprimidos sobre os quais nossa tradição intelectual de esquerda tem tido muito pouco o que dizer.

Em outras palavras, o pavor do alçamento das classes oprimidas de que nos fala Darcy Ribeiro tem sido quase uma regra, mesmo entre nossos intelectuais de esquerda. A expressão máxima deste pavor é a brutalidade repressiva e criminalizadora, bem como a obsessão pela ordem que acompanhou toda a nossa história. Nosso desafio atual é como organizar o inorgânico, construindo uma consciência de grupo que lhe faculte a mudança e a justiça social. Alguns passos têm sido dados, não sem ambiguidades: os sem terra, os sem teto, o movimento de periféricos, etc. Por isso é que o endurecimento penal tem sido o lado complementar, espécie de irmão siamês daquele sentimento anti-povo predominante entre nossas elites. 
Neste artigo buscou-se refletir sobre o lugar destes oprimidos como os excluídos da história. Mostrou-se, sobretudo, o esforço de nossas elites no sentido de aquietá-los na ordem excludente criada desde os tempos coloniais: na medida em que não vão compor a massa de operários das fábricas em nascimento, serão pouco a pouco absorvidos pelo trabalho informal ou pelas estatísticas criminais que acabavam de nascer. Mas mostrou-se, igualmente, que nas condições periféricas do capitalismo brasileiro de fins do século XIX, o castigo cumpria um duplo propósito: disciplinar o trabalho e reduzir os desvios. Assim também o modo de punir: suplício para uns, isolamento ou trabalho para outros. Viu-se que estas indefinições jurídicas tinham a ver com as profundas diferenças hierárquicas que se estabeleceram na sociedade brasileira desde o período colonial.

Em outras palavras, em fins do século XIX, nas condições de profundo atraso da indústria nacional, as casas de correções dos séculos XVII e XVIII na Europa continuavam a manter um importante papel de disciplinamento do trabalho. Mas, paralelamente, o encarceramento correspondia ao medo das elites rurais do país de uma "vingança negra" generalizada; daí por que os crimes contra a pessoa eram os mais severamente reprimidos. Por outro lado, havia que se estabelecer o controle social sobre o refugo do trabalho colonial, os homens pobres e livres, que se avolumava à medida que crescia o movimento de libertação dos escravos.

\section{Bibliografia}

AZEVEDO, Celia Maria Marinho de. Onda negra, medo branco. São Paulo: AnnaBlume, 2004 .

BATISTA, Vera Malaguti. Introdução crítica à criminologia brasileira. Rio de Janeiro: Revan, 2014 .

BRAGA, "Quem, é o em http://www.boitempoeditorial.com.br/v3/Noticias/visualizar/3743

CARVALHO, José Murilo. A construção da ordem; Teatro de sombras. Rio de Janeiro: RelumeDumará, 1996.

CONRAD, Robert. Os últimos anos da escravatura no Brasil. Rio de Janeiro: Civilização Brasileira, 1975.

COUTO, José Luiz de Almeida. Fala dirigida à Assembleia Legislativa Provincial de S. Paulo na abertura da segunda sessão da $26^{\mathrm{a}}$ legislatura em io de janeiro de I885. São Paulo: Typ. Da Gazeta Liberal, I885.

ELIAS, Norbert. O processo civilizador. Rio de Janeiro: Zahar, $201 \mathrm{I}$. 
FERNANDES, Florestan. A integração do negro na sociedade de classes, v. I. São Paulo: Ática, 1978.

FERREIRA, Ricardo Alexandre. "O tronco na enxovia: escravos e livres nas prisões paulistas dos oitocentos”. In: Marcos Luiz Bretas et all (org.). História das prisões no Brasil, v. I. Rio de Janeiro: Rocco, 2009.

FOUCAULT, Michel. Vigiar e punir. Petrópolis: Vozes, 1986.

FRANCO, Maria Silvia de Carvalho. Homens livres na ordem escravocrata. São Paulo: Kairós, 1983.

GEBARA, Ademir. O mercado de trabalho livre no Brasil (I87I-I888). São Paulo: Brasiliense, 1986.

GUIMARÃES, Alberto Passos. As classes perigosas. Rio de Janeiro: UFRJ, 2008.

HOBSBAWM, Eric J. Bandidos. Rio de Janeiro: Paz e Terra, 2015.

LARA, Silvia Hunold. Campos da violência. Rio de Janeiro: Paz e Terra, 1988.

LUKÁCS, G. História e consciência de classe. Porto: Escorpião, 1989.

MARX, K. O capital, livro I, v. 2. Rio de Janeiro: Civilização Brasileira, 2014.

MARX, K. O I8 Brumário de Luís Bonaparte (I852). In: Obras escolhidas, v. I. São Paulo: AlfaOmega, s.d.

MELOSSI, Dario; PAVARINI, Massimo. Cárcere e fábrica. Rio de Janeiro: Revan-ICC, 2006 (I977).

MOTTA, Vicente Pires da. Discurso com que o ilustríssimo e excelentíssimo o presidente da província de S. Paulo abriu a Assembleia Legislativa Provincial no dia 15 de abril de I850. São Paulo: Typ. Do Governo, I850.

MOURA, Denise A. Soares de. "Relações de trabalho e convívio em um município paulista cafeeiro (Campinas, I87I-I885)”. In: Nilo Odália e João Ricardo de Castro Caldeira (orgs.). História do Estado de São Paulo, v. I. São Paulo: Unesp, 2010.

MÜLLER, Daniel Pedro. Ensaio d’um quadro estatístico da província de São Paulo. São Paulo: Costa Silveira, I837.

OLIVEIRA, Francisco de. Crítica à razão dualista/O ornitorrinco. São Paulo: Boitempo, 2013.

OLIVEIRA, Francisco de. A era da indeterminação. São Paulo: Boitempo, 2007.

PRADO Jr, Caio. Formação do Brasil contemporâneo. São Paulo: Brasiliense, 1995.

RIBEIRO, Darcy. O povo brasileiro. São Paulo: Companhia das Letras, 2006.

SAINT-HILAIRE, Auguste de. Viagem à província de São Paulo. Belo Horizonte: Itatiaia, 1976 (I85I). 
SILVA, Antonio da Costa Pinto. Relatório apresentado à Assembleia Legislativa Provincial de S. Paulo pelo presidente de província no dia 5 de fevereiro de I87I. São Paulo: Typ. Americana, I87I.

SOARES, João Crispiniano. Relatório apresentado à Assembleia Legislativa Provincial de São Paulo na segunda sessão da décima quinta legislatura no dia 2 de fevereiro de I865. São Paulo: Typ. Imparcial, I865.

WEBER, Max. A ética protestante e o espírito do capitalismo. São Paulo: Martin Claret, 2007. ZAFFARONI, E. Raúl. O inimigo no direito penal. Rio de Janeiro: Revan, 2014. 